HORTICULTURE

\title{
Standardization of Organic Manure and Bio-inoculants for Production of Improved Planting Material of Tea
}

\author{
Kaki Ranjit ${ }^{1 *}$, Himadri Bhattacharjee ${ }^{1}$ and Venkata Satish Kuchi ${ }^{2}$ \\ ${ }^{1}$ Department of Plantation Crops and Processing, FOH, Main Campus, Pundibari, UBKV, West Bengal, India \\ ${ }^{2}$ Department of Horticulture, MS Swaminathan School of Agriculture, Centurion University of Technology and Management, \\ Paralakhemundi, Gajapati, Odisha, India
}

"Corresponding author: kakiranjit@gmail.com (ORCID ID: 0000-0001-5974-4694)

Paper No. 815

Received: 24-09-2019

Revised: 18-01-2020

Accepted: 29-02-2020

\begin{abstract}
Tea is one of the important plantation crops of India as well as West Bengal, contributes considerably in national economy and earns foreign exchange. During 2014-15, total production of tea in India was $1233.14 \mathrm{~m} \mathrm{~kg}$, out of which only $100 \mathrm{~m} \mathrm{~kg}$ were organic tea. Mainly due to importers demand of organic tea, there is urgent need to enhance organic production of tea crop. Indiscriminate use of inorganic agricultural inputs-fertilizers, weedicides, pesticide and fungicides and lesser use of organic matters deplete soil health, residues remain beyond MRL in processed tea, ultimately reduction in export. Tea Board provides 55\% subsidy for organic tea production. For organic cultivation of tea, the planting materials should also be organically produced in nursery, which is very scanty for perennial crops in general and plantation crops in particular. With this background, the present investigation was carried out at instructional farm of the department of Plantation Crops and Processing, UBKV, Pundibari, with the objective to standardize the organic manures and bio-inoculants for production of improved planting materials of tea, The experiment was conducted from 2013 to 2015 and laid out in completely randomized block design. The planting materials of tea chosen to standardize organic manures and bio-inoculants were TS-462 and TV 26. From the study it can be inferred that, the treatment $\mathrm{T}_{6}$-vermicompost $50 \mathrm{~g} / \mathrm{sleeve}$ and bio fertilizers mixture $10 \mathrm{~g}$ (Azotobacter + Azospirillium + PSB + Trichoderma + VAM @2.0 g each)/sleeve observed to be the best when compared to other treatments and control.
\end{abstract}

\section{Highlights}

(0 Present study was thus carried out with the objective to standardize the organic and bio-inoculants for production of improved planting materials of tea

Keywords: Tea nursery, organic manures, bio-inoculants and planting materials

Tea (Camellia sinensis (L.) O. Kuntze) belongs to family Theaceae is one of the most economically important evergreen woody plantation crops predominantly grown in the subtropical regions of India. It is most popular and low cost beverage in the world and consumed by a large number of people. Tea is grown mainly for young tender apical two leaves and a bud, which is a rich source of polyphenols, caffeine etc. Owing to its increasing demand, tea is considered to be one of the major components of world beverage market.
The plantation crops are high value commercial crops of great economic importance and play a vital role in Indian economy. India was the second largest producer of tea in the world, grown in an area of about 563.98 thousand ha with a production of 1,233.14 million $\mathrm{kg}$ which was about $23 \%$ of total world production. About $80 \%$ of the production was consumed internally which was about $21 \%$ of the total world consumption. During the same period India exported 232.92 million $\mathrm{kg}$ and valued at US\$ 686.67 million and ranked fourth in terms of export 
of tea. The tea industry is India's second largest employer with over 3.5 million people across some 1,686 estates and 1,57,504 small holdings; most of them are women. In West Bengal, tea was grown in an area of 140.44 thousand ha and production was about 312.10 million $\mathrm{kg}$ (IBEF, 2016). Over the last 20 years, India's world ranking as an exporter of tea has come down from number one to number four, in the face of stiff competition from Sri Lanka, Kenya, and China (Majumdar et al. 2012). Main importing countries of Indian tea were Russian Federation (48.23 million $\mathrm{kg}$ ), Iran (22.13 million $\mathrm{kg}$ ) and Pakistan (19.37 million kg). Recent trends showed drastic reduction in tea exports from India, as the importing countries prefered residue free superior quality tea. Only one per cent of total tea produced in India is organic tea. However, organic tea constituted only two per cent of the total organic products exported from India during 2012-13 (FAO, 2014).

An organic product is free from chemicals, antibiotics, synthetic hormones, genetic modifications and field use of sewage sludge as fertiliser. Organic cultivation is a sustainable way to combat climate change. Use of naturally available products, such as organic manure or compost, increases climate resilience. A minimum of three years is needed for an established conventional garden to be converted to organic, which has to be certified by a certifying agency. The problems for established tea gardens that wish to go organic are two fold, i.e., yield drop up to an extent of 44 per cent and over 65 per cent increase in cost of production as compared to the conventional cultivation (Goswami 2015; FAO. 2014). In India, the cultivation of organic tea started during 1986 and gradually spread to the tea areas of West Bengal, Assam and South India (Prayukth 2005). For establishment of organic tea plantation, the planting materials also have to be produced following organic methods. Tea nurseries generally use chemical inputs especially fertilizers and plant protection chemicals for production of planting materials which affect the physical and chemical properties of soil, leaves residues and disturb ecosystem. Therefore, inputs chosen for better planting material production also play key role to guarantee the desired crop performance and economic returns to the farmers. For producing planting materials of tea using nutrients in elemental forms and organic inputs like farm yard manure, vermicompost, biofertilizers and biopesticides.

Organic manures are main source of plant nutrition in organic farming due to its multiple functions in soil (Mamaril et al. 1986). The important organic amendments are crop residues, vermicompost, farm yard manure and green manure and use of these inputs are increasingly becoming important aspects of environmentally sound sustainable agriculture (Timsina and Connor 2001). The basic principle of plant nutrition is universal but optimum fertilizer requirement will vary with plant types and nature of soil. Nitrogen, phosphorus and potassium are the major nutrients required by the plants. Other nutrients required are calcium, sulphur and magnesium. Nitrogen is an important constituent of chlorophyll, amino acids, proteins and nucleic acids. Phosphorus is one of the vital nutrients that could be limiting in tea soils. It is responsible for cell division and plays a key role in the formation of new wood and root. While, potassium plays a key role as an activator of enzymes involved in carbohydrate and protein metabolism, membrane permeability and stomatal opening (Marschner 2012).

Biofertilizers are carrier based preparations containing beneficial microorganisms in a viable state. They improve soil fertility and help in plant growth by improving nutrient availability. Nitrogen fixers and phosphate solubilizers are naturally present in almost all soils but their population level may not be sufficient to bring out these biological processes to a significant level. Addition of efficient strains of these microorganisms was successfully practised in many crops (Pandya and Saraf 2010).

The use of biofertilizers and organic manure offer a great opportunity to increase the crop productivity with less cost. With this objective, experiments were conducted to find out the success of biofertilizers in an organic farming system. The beneficial microorganisms are generally applied through various carrier materials. Without carrier materials, the applied beneficial microorganisms will not survive for longer period. The carrier materials should have high organic matter content, high water holding capacity, neutral $\mathrm{pH}$ for better survival of the organisms. Various organic materials and agricultural wastes such as composted coir pith, lignite, organic manure, vermicompost and 
vermiculite were tested as carrier materials in vitro and field conditions to select.

\section{MATERIALS AND METHODS}

For the present investigation, a temporary nursery was in the instruction cum research plot of the Department of Plantation Crops and Processing, UBKV, Pundibari, during 2013-2015. The details of various materials used and methods employed in the investigation have been presented below.

The experimental site was the instruction cum research plot of Department of Plantation Crops and Processing, UBKV, located at $26^{\circ} 19^{\prime} 86^{\prime \prime}$ N Latitude and $89^{\circ} 23^{\prime} 53^{\prime \prime}$ E Longitude at an elevation of $43 \mathrm{~m}$ above mean sea level. Agro climatologically, the location represents Terai region of West Bengal and is characterized by subtropical climate. The place experiences hot summers, hot and humid rainy season and cool winters. In the nursery, beds of size $1.2 \mathrm{~m}$ width and $13 \mathrm{~m}$ length were prepared in East-West direction with a drain of $30 \mathrm{~cm}$ in between the two beds. All the beds were covered using green coloured agronet (50\% light transmittance) on all the sides, a height of $2.0 \mathrm{~m}$ on Northern side and $1.5 \mathrm{~m}$ on Southern side was maintained. For filling (black polythene) sleeves of size $20 \times 30 \mathrm{~cm}$, lay flat 250 guage thickness, sealed at the bottom, punctured eight holes on the lower one-third, which can hold $2.5 \mathrm{~kg}$ soil. Top soil from the plantation area was collected dried, pulverized and sieved through an $8 \mathrm{~mm}$ mesh size of sieve. Similarly, FYM and VC were also dried, pulvurized, sieved and heaped separately, then mixed with the soil at required rates.

The experimental materials for the present investigation comprised of biclonal seed stock of tea viz., TS-462 released by Tocklai Experimental Station (Tocklai Tea Research Institute), Tea Research Association, Jorhat, Assam and the vegetative clone TV 26 released by TRA respectively. Different organic nutrients sources such as farm yard manure (FYM) and vermicompost (VC) were collected from Directorate of Farms, UBKV, Pundibari and bio- inoculants such as Azotobacter, Azospirillium, Phosphate solubulising bacteria (PSB), Trichoderma, vesicular arbuscular mychorrhiza (VAM) were collected from bio-control unit of the Department of Plant Pathology, UBKV, Pundibari. All other chemicals used during investigation for analysis of soil, FYM, VC and for microbial culture requisite chemicals with AR or GR grades were purchased from the authorized dealer of Hi-Media and Merck Mumbai, India located at Jalpaiguri, West Bengal.

The experimental plot was situated at the departmental plot of the Department of Plantation Crops and Processing, UBKV, Pundibari. The experimental plot was laid out in shade net under young aged (6 years) arecanut garden in North South direction, the interspaces among the garden are utilized by preparing raised beds with proper drainage facilities in East-West direction. The polythene sleeves filled up with fine sieve soils and organic manures are kept systematically i.e., treatment wise. Seeds were placed in aluminium trays containing 5-7 cm thick layer of sand then covered with fine shallow layer of seived sand for proper cracking and then moisture provided at alternate days for proper sprouting and germination. It took 18 days to complete cracking and sprouting. Later on cracked seeds are sown at depth of 3-5 cm in polythene sleeves filled up with fine sieve soils and organic manures which are kept systematically i.e., treatment wise.

Irrigation: After transplanting once light irrigation was given for quick establishment of seedlings followed by pouring water whenever irrigation is required.

Hoeing and weeding: The experimental beds and sleeves are kept free from weeds by hand weeding. Drainage channels around the raised beds are cleared at periodic intervals. Sometimes water accumulated in polythene sleeves are removed by puncturing with nail, which allow excess water to drain out.

Pest and disease management: Incidence of pests were observed, to check the infestation of pests neem oil at a concentration of $0.1 \%$ was sprayed at monthly intervals.

To standardize organic manures and bio-inoculants for production of improved planting materials of tea, one each of seed stock and clone chosen viz., TS-462 and TV 26 separately and carried out the experiment. The treatment details are, total six treatments combinations with four replications of 37 plants each with 150 sleeves per treatment taken. Different organic supplements like farm yard manure@100 g per sleeve, vermicompost @ $50 \mathrm{~g}$ 
per sleeve, mixture of biofertilizers as bio-inoculants about $10 \mathrm{~g}$ per sleeve added according to treatment combinations. For statistical analysis complete randomized design opted.

\section{Treatment details}

\begin{tabular}{lll}
\hline Treatments & Treatment details & No. of plants \\
\hline $\mathrm{T}_{1}$ & (only soil) Control & 150 \\
$\mathrm{~T}_{2}$ & Soil + FYM @ $100 \mathrm{~g}$ & 150 \\
$\mathrm{~T}_{3}$ & Soil + VC @ $50 \mathrm{~g}$ & 150 \\
$\mathrm{~T}_{4}$ & Soil + Bio-inoculants $10 \mathrm{~g}$ & 150 \\
$\mathrm{~T}_{5}$ & Soil + FYM @ $100 \mathrm{~g}+$ Bio- & 150 \\
& inoculants $10 \mathrm{~g}$ \\
$\mathrm{~T}_{6}$ & Soil + VC @ $50 \mathrm{~g}+$ Bio- & \\
\hline
\end{tabular}

*(Azotobacter + Azospirillium + PSB $^{*}+$ Trichoderma + VAM ${ }^{* *} @$ $2.0 \mathrm{~g}$ each)

*phosphorous solublising bacteria **esicular arbuscular mycorrhiza

Parameters recorded: For taking observations on various parameters five plants were randomly selected from each replication with specific tagging of particular treatments at 120, 210, 300, 390 and 480 days after sowing the seeds or planting of callused cuttings and observations were recorded, plant height i.e., the height of plants was measured from bottom to tip of the main stem and was expressed in centimetre(s) followed by number of leaves per plant i.e., total number of leaves were counted in five selected plants and expressed as number of leaves per plant then number of branches per plant i.e., total number of branches arising from the main stem were counted and presented as number of branches per plant and finally collar girth of plants i.e., the girth of plants was measured at collar region at $1.0 \mathrm{~cm}$ from soil level of main stem with Vernier callipers and expressed in $\mathrm{mm}$.

Statistical Analysis: The data collected on growth of tea seedlings and clones were observed and recorded at ninety days intervals. As this experiment was conducted in an enclosed nursery under shade net, the design chosen for analysis was Complete Randomised Design (CRD). Data were analyzed using SPSS software, the analysis of variance (ANOVA) and the treatment mean values were compared by Duncan's Multiple Range Test (DMRT) at $\mathrm{P} \leq 0.05$ for significance level. The standard error of mean and critical difference are indicated in the
Tables. For determination of critical differences at $5 \%$ and $1 \%$ level of significance, Fisher and Yates (1963) tables were consulted.

\section{RESULTS AND DISCUSSION}

Various observations recorded on plant height for the seed stock stock TS-462 and clone TV 26 from 120 to 480 days after sowing or transplanting (DAS/ DAT) have been presented in Table 1.

It is evident from data that, in tea seedlings of stock TS-462, initially on 120 and 210 DAS maximum plant height of $13.13 \mathrm{~cm}$ and $27.88 \mathrm{~cm}$ were observed under $\mathrm{T}_{3}$ (Soil $+\mathrm{VC}$ ) and minimum of $9.31 \mathrm{~cm}$ and $20.50 \mathrm{~cm}$ was recorded under $\mathrm{T}_{1}$ (control) plants. On 300, 390 and 480 DAS maximum plant height $38.94 \mathrm{~cm}, 50.75 \mathrm{~cm}$ and $64.67 \mathrm{~cm}$ was recorded in treatment $\mathrm{T}_{5}$ (Soil + FYM + biofertilizers). Minimum plant height was shown by the seedlings under controlled treatment $\left(\mathrm{T}_{1}\right)$ on all observations respectively. It is depicted from the data, that clonal plant of TV 26 had maximum plant height of 12.65 $\mathrm{cm}, 26.00 \mathrm{~cm}, 35.42 \mathrm{~cm}, 44.83 \mathrm{~cm}$ and $51.08 \mathrm{~cm}$ in treatment $\mathrm{T}_{5}$ (Soil + FYM + biofertilizers) on all observations. Whereas minimum plant height 9.95 $\mathrm{cm}, 20.05 \mathrm{~cm}, 22.28 \mathrm{~cm}, 24.50 \mathrm{~cm}$ were observed in $\mathrm{T}_{3}$ (Soil $+\mathrm{VC}$ ) treatment initially i.e., at 120, 210, 300 and 390 DAT respectively. However, on final observations on $480 \mathrm{DAT}$, minimum plant height of $33.50 \mathrm{~cm}$ was observed in $\mathrm{T}_{1}$ (control) treatment. Data from Table on plant height depicted that in both the planting materials of seed stock TS-462 and clone TV 26 significant differences were observed on all observations.

Morphological parameters of the nursery plants in response to organic matters and bio-inoculation: In the present investigation, it was observed that, the seedlings of TS-462 had maximum plant height of $38.94 \mathrm{~cm}, 50.75 \mathrm{~cm}$ and $64.67 \mathrm{~cm}$ on 300,390 and 480 DAS respectively under $\mathrm{T}_{5}$ (Soil + FYM @100g + BF @10g). Whereas, clonal plant of TV 26 had maximum plant height of $51.08 \mathrm{~cm}$ in treatment $\mathrm{T}_{5}$ (Soil $\left.+\mathrm{FYM}+\mathrm{BF}\right)$ on all observations, which was in conformity with Choubey et al. (2013). The effect of biofertilizer treatments on vegetative growth of tomato was significantly higher plant height and number of leaves than control plants (Ramakrishnan and Selvakumar 2012). In sesamum, shoot length of variety RT-54 and JLT-7 significantly affected by Azotobacter, while in variety GT-1, 
Table 1: Effect of organic manures and bio-inoculants on plant height for seedlings of TS-462 and clonal plants of TV 26

\begin{tabular}{|c|c|c|c|c|c|c|c|c|c|c|}
\hline \multirow[b]{3}{*}{ Treatment } & \multicolumn{10}{|c|}{ Plant height $(\mathrm{cm})$ on DAS / DAT } \\
\hline & \multicolumn{5}{|c|}{ TS-462 } & \multicolumn{5}{|c|}{ TV 26} \\
\hline & 120 & 210 & 300 & 390 & 480 & 120 & 210 & 300 & 390 & 480 \\
\hline $\mathrm{T}_{1}(\mathrm{CONTROL})$ & $9.31^{\mathrm{d}}$ & $20.50^{b}$ & $25.00^{c}$ & $29.50^{c}$ & $37.08^{c}$ & $10.30^{a b}$ & $20.55^{b}$ & $23.03^{c}$ & $25.50^{b}$ & $33.50^{\mathrm{c}}$ \\
\hline $\mathrm{T}_{2}$ Soil + FYM & $10.94^{\mathrm{bcd}}$ & $23.31 \mathrm{ab}$ & $29.66^{b c}$ & $36.00 \mathrm{bc}$ & $50.50 \mathrm{ab}$ & $12.05^{a b}$ & $24.55^{\mathrm{ab}}$ & $28.19 \mathrm{abc}$ & $31.83^{a b}$ & $44.00^{\mathrm{ab}}$ \\
\hline $\mathrm{T}_{3}$ Soil + VC & $13.13^{\mathrm{a}}$ & $27.88^{a}$ & $35.91 \mathrm{ab}$ & $43.94^{a b}$ & $56.92^{a}$ & $9.95^{b}$ & $20.05^{b}$ & $22.28^{c}$ & $24.50^{\mathrm{b}}$ & $37.25^{b c}$ \\
\hline $\mathrm{T}_{4}$ Soil + BF & $9.81^{\mathrm{cd}}$ & $21.00^{b}$ & $34.54 \mathrm{ab}$ & 48.09 a & $48.75^{a b}$ & $11.10^{a b}$ & $22.40 \mathrm{ab}$ & $24.83^{b c}$ & $27.25^{b}$ & $38.08^{b c}$ \\
\hline $\mathrm{T}_{6}$ Soil + VC+BF & $11.47 \mathrm{abc}$ & $22.38^{a b}$ & $35.90^{a b}$ & $49.42^{\mathrm{a}}$ & $63.58^{a}$ & $12.25^{a b}$ & $24.60 \mathrm{ab}$ & $31.34^{\mathrm{ab}}$ & $38.08^{a}$ & $44.83^{\mathrm{ab}}$ \\
\hline $\operatorname{SEm}( \pm)$ & 0.599 & 1.883 & 2.025 & 3.657 & 5.670 & 0.735 & 1.493 & 2.489 & 4.647 & 2.863 \\
\hline CD at (0.05) & 1.778 & 5.595 & 6.018 & 10.866 & 16.847 & 2.184 & 4.437 & 7.394 & 13.806 & 8.505 \\
\hline $\mathrm{CD}$ at $(0.01)$ & 2.436 & 7.666 & 8.245 & 14.888 & 23.082 & 2.993 & 6.079 & 10.131 & 18.915 & 11.653 \\
\hline
\end{tabular}

Table 2: Effect of organic manures and bio-inoculants on number of leaves for seedlings of TS-462 and clonal plants of TV 26

\begin{tabular}{|c|c|c|c|c|c|c|c|c|c|c|}
\hline \multirow[b]{3}{*}{ Treatment } & \multicolumn{10}{|c|}{ Number of leaves per plant on DAS / DAT } \\
\hline & \multicolumn{5}{|c|}{ TS-462 } & \multicolumn{5}{|c|}{ TV 26} \\
\hline & 120 & 210 & 300 & 390 & 480 & 120 & 210 & 300 & 390 & 480 \\
\hline $\mathrm{T}_{1}(\mathrm{CONTROL})$ & $6.13^{c}$ & $9.00^{\mathrm{b}}$ & $9.94^{\mathrm{b}}$ & $10.88^{b}$ & $20.31^{b}$ & 4.10 & $8.70^{\mathrm{b}}$ & $8.91^{\mathrm{b}}$ & $9.13^{\mathrm{b}}$ & $17.50^{\mathrm{d}}$ \\
\hline $\mathrm{T}_{2}$ Soil +FYM & $7.75^{b}$ & $10.06^{\mathrm{b}}$ & $13.38^{b}$ & $16.69^{b}$ & $25.38^{b}$ & 4.40 & $9.50 \mathrm{ab}$ & $13.74^{\mathrm{a}}$ & $17.98^{\mathrm{a}}$ & $24.00 \mathrm{bc}$ \\
\hline $\mathrm{T}_{3}$ Soil +VC & $9.38^{a}$ & $13.81^{\text {a }}$ & $15.84^{\mathrm{b}}$ & $17.88^{b}$ & $23.94^{\mathrm{b}}$ & 4.60 & $8.90^{\mathrm{b}}$ & $10.35^{b}$ & $11.80^{b}$ & $19.83^{\mathrm{cd}}$ \\
\hline $\mathrm{T}_{4}$ Soil + BF & $7.63^{b}$ & $9.44^{\mathrm{b}}$ & $12.59^{b}$ & $15.75^{b}$ & $21.25^{b}$ & 4.20 & $8.70^{\mathrm{b}}$ & $9.85^{b}$ & $11.00^{b}$ & $19.42^{\mathrm{cd}}$ \\
\hline $\mathrm{T}_{6}$ Soil +VC+BF & $10.50^{\mathrm{a}}$ & 16.69 a & $23.00^{\mathrm{a}}$ & $29.31^{\mathrm{a}}$ & $45.13^{a}$ & 4.60 & $10.95^{a}$ & $15.85^{a}$ & $20.75^{a}$ & $24.75^{b}$ \\
\hline $\operatorname{SEm}( \pm)$ & 0.492 & 1.197 & 1.975 & 3.001 & 3.196 & 0.235 & 0.520 & 0.963 & 1.728 & 1.487 \\
\hline $\mathrm{CD}$ at $(0.05)$ & 1.462 & 3.557 & 5.868 & 8.917 & 9.496 & NS & 1.546 & 2.861 & 5.134 & 4.417 \\
\hline $\mathrm{CD}$ at $(0.01)$ & 2.003 & 4.873 & 8.040 & 12.217 & 13.011 & 0.958 & 2.118 & 3.919 & 7.034 & 6.052 \\
\hline
\end{tabular}

shoot length significantly influenced by $P S B$ and Azotobacter with PSB. In sesamum varieties GT-1, showed highest root length, shoot length, available nitrogen and phosphorous (Kushwaha 2011). Aggani (2013) opined that PSBs significantly promoted the height and fresh weight of tomato and muskmelon seedlings. The propagating stem length of watermelon inoculated with PSB suspension was $60 \mathrm{~cm}$ longer than that of non-inoculated plants. Application of biofertilizer had a significant effect on plant height and number of branches per plant. Biofertilizer rhizobium produced the highest values in respect, compared to the Azospirillum (Priya and Elakkiya 2012). The increment in vegetative growth due to biofertilizer application might be due to the vital role of bacteria present in the applied biofertilizer and capable of contributing some hormonal substances (Cacciari and Pietrosanti 1989). Application of manures increased all vegetative growth such as plant height increment, lateral shoot numbers, stem diameter, number of leaves per seedling, dry weight of leaves and root numbers per seedling as well as nitrogen, potassium and phosphorus contents in leaf of seedlings (Laila et al. 2015).

Various observations recorded on number of leaves per plant of seed stock TS-462 and clone TV 26 from 120 to 480 days after sowing or transplanting (DAS/DAT) have been presented in Table 2. In tea seedlings of Stock TS-462, number of leaves per seedling on 120 days after sowing (DAS) was maximum (10.50) when bio-inoculants were added with vermicompost $\left(\mathrm{T}_{6}\right)$ and minimum (6.13) was recorded under control $\left(\mathrm{T}_{1}\right)$ plants. At 210 DAS, number of leaves was highest with 16.69 leaves at treatment combination of vermicompost applied with biofertilizers, followed by 15.75 leaves when farm yard manure (FYM) in combination with biofertilizers were used. While, VC and FYM alone with soil produced 13.81 and 10.06 leaves per seedlings respectively. However, performance of seedlings on 300 and 390 DAS were also generally 
superior when biofertilizers were added with vermicompost $\left(\mathrm{T}_{6}\right)$. On $480 \mathrm{DAS}$, the superior results with respect to number of leaves i.e., 45.13 per plant were observed when biofertilizers with VC were used as potting mixture. For all other treatments the number of leaves ranged from 20.31 to 30.19, which were statistically not different. It is evident that vegetative growth of tea clone TV 26 with respect to number of leaves per clone was maximum when vermicompost applied with bio-fertilizers and minimum at controlled treatment. The data revealed that number of leaves for clonal plants of TV 26, on 120 DAT was maximum (4.85) when farm yard manure in combination with biofertilizers were used and minimum (4.10) at controlled treatment $\left(\mathrm{T}_{1}\right)$. In all the observations, plants with controlled treatment had consistently least number of leaves ranging from 4.10 on 120 DAT to 17.50 on 480 DAT per plant. The number of leaves per plant on 210 DAT observed were 10.95. On 300 and 390 DAT number of leaves were found to be higher with 15.85 and 20.75, respectively when biofertilizers were applied with vermicompost $\left(\mathrm{T}_{6}\right)$. Which were at par with 14.64, 13.74 and 19.83 and 17.98 leaves with $\mathrm{T}_{5}$ and $\mathrm{T}_{2}$ respectively. On 480 DAT, FYM and bioinoculants combination showed superior result with 29.66 leaves per plant. The data revealed that there were significant differences among all the treatment combinations and observations for number of leaves per plant, for both the seedling of TS-462 and clonal plants of TV 26, except in clonal plants on 120 DAT, which was observed to be non-significant values.

It was observed that number of leaves per seedling from 120 DAS to 480 DAS in all the treatments produced a minimum of 6.13 (control) to 45.13 leaves $\left(T_{6}\right)$. Among the treatments $\left(T_{1}\right.$ to $\left.T_{6}\right)$, all the seedlings under $T_{6}$ produced consistently more number of leaves from 120 to 480 DAS except on 390 DAS maximum (29.38) were produced under $\left(T_{5}\right)$, which was slightly higher than the number of leaves produced (29.31) at $\mathrm{T}_{6}$. Tea Research Association, Jorhat, Assam recommended that the plantable plants of tea should have a minimum of sixteen to eighteen normal leaves at the time of transplanting to the main field. Out of eight tea clones observed in Darjeeling Choubey et al. (2013) recorded the number of leaves per plant ranged 39.78 in clone T-78. Maximum number of 14.25 leaves were produced on six months old nursery plants of tea from cuttings in Pakistan (Islam et al. 2015). Application of $15 \mathrm{~kg} \mathrm{~N}$ as Borreria and 30 $\mathrm{kg} \mathrm{N}$ as urea/ha significantly increased number of leaves in clonal plants of TV 22 (Saloi and Deka 1996) at Jorhat, Assam. Rajendran and Jayasree, (2007) also observed that maximum growth and biomass were recorded in Rhizobium + AM + Azospirillum combination and it was $156.8 \%$ more than the control.

Data obtained on number of branches per plant for the seedlings of stock and clone chosen have been presented in Table 3. It is clear that in tea seedlings of Stock TS-462, number of branches per plant on 120 DAS ranged from $1.25\left(\mathrm{~T}_{1}\right)$ to $2.13\left(\mathrm{~T}_{6}\right)$, which were statistically non significant. On 210 and 480 DAS 3.00, 8.67 were maximum when vermicompost was applied with bio-fertilizer $\left(\mathrm{T}_{6}\right)$ and minimum (1.33) was recorded in the treatment $\mathrm{T}_{2}$ (Soil + FYM) and least number of (2.06) branches was noticed in control $\left(\mathrm{T}_{1}\right)$ on 480 DAS. Whereas, on 300 and 390 DAS maximum number of branches (3.46) and (4.04) were observed in treatment $\mathrm{T}_{5}$ (Soil + FYM + biofertilizers) and minimum of 1.25 and 1.75 branches were recorded under treatment $\mathrm{T}_{1}$ (control). For the clone TV 26, there were no branches up to 210 DAT, from 300 DAT only branches appeared in all the treatments. Maximum number of 4.73 and 5.99 branches per clonal plant was recorded in treatment $\mathrm{T}_{5}$ (Soil + FYM + biofertilizers) and minimum number of $1.25,1.65$ and 2.50 branches were observed in $\mathrm{T}_{1}$ (control) treatment on 300, 390 and 480 DAT, respectively. However, 5.16 number of branches were observed under T6 (Soil + VC + biofertilizers) on 480 DAT. For number of branches per plant shown in Table 4.01.03 the data depicted significant differences for both, seed stock TS-462 and clone TV 26 except on 120 DAS for seedlings of TS-462 and 300 DAT in case of clone TV 26, which showed non significant results.

The seedlings of Stock TS-462 produced maximum number of 3.00 branches on 210 DAS and 8.67 branches on 480 DAS when vermicompost was applied with biofertilizer $\left(\mathrm{T}_{6}\right)$. In case of clones, maximum number of 4.73 and 5.99 branches per clonal plant was recorded in treatment $\mathrm{T}_{5}$ (Soil + FYM + bio inoculants) on 390 and 480 DAT respectively. Radhakrishnan and Mahendran, (2007) also observed number of branches per plant was greatest when grown in red soil with vermicompost 
Table 3: Effect of organic manures and bio-inoculants on number of branches for seedlings of TS-462 and clonal plants of TV 26

\begin{tabular}{|c|c|c|c|c|c|c|c|c|c|c|}
\hline \multirow[b]{3}{*}{ Treatment } & \multicolumn{10}{|c|}{ Number of branches per plant on DAS / DAT } \\
\hline & \multicolumn{5}{|c|}{ TS-462 } & \multicolumn{5}{|c|}{ TV 26} \\
\hline & 120 & 210 & 300 & 390 & 480 & 120 & 210 & 300 & 390 & 480 \\
\hline $\mathrm{T}_{1}(\mathrm{CONTROL})$ & 1.25 & $1.50^{\mathrm{ab}}$ & $1.25^{c}$ & $1.75^{\mathrm{b}}$ & $2.06^{c}$ & 0.00 & 0.00 & 1.25 & $1.65^{\mathrm{c}}$ & $2.50^{b}$ \\
\hline $\mathrm{T}_{2}$ Soil + FYM & 1.45 & $1.33^{\mathrm{b}}$ & $1.50 \mathrm{bc}$ & $2.00^{b}$ & $2.59^{c}$ & 0.00 & 0.00 & 1.45 & $2.73 \mathrm{bc}$ & $3.08^{b}$ \\
\hline $\mathrm{T}_{3}$ Soil + VC & 1.50 & $1.50 \mathrm{ab}$ & $2.00 \mathrm{bc}$ & $2.50^{\mathrm{b}}$ & $2.79 \mathrm{bc}$ & 0.00 & 0.00 & 1.50 & $1.53^{c}$ & $3.41^{b}$ \\
\hline $\mathrm{T}_{4}$ Soil + BF & 1.38 & $1.79 \mathrm{ab}$ & $1.67 \mathrm{bc}$ & $2.06^{\mathrm{b}}$ & $2.58^{c}$ & 0.00 & 0.00 & 1.38 & $2.07^{c}$ & $3.50^{b}$ \\
\hline $\mathrm{T}_{6}$ Soil + VC+BF & 2.13 & $3.00^{\mathrm{a}}$ & $2.25^{b}$ & $3.00 \mathrm{ab}$ & $8.67^{a}$ & 0.00 & 0.00 & 2.13 & $3.89 \mathrm{ab}$ & $5.16^{\mathrm{a}}$ \\
\hline $\operatorname{SEm}( \pm)$ & 0.267 & 0.352 & 0.269 & 0.418 & 0.484 & 0.00 & 0.00 & 0.267 & 0.481 & 0.411 \\
\hline $\mathrm{CD}$ at $(0.05)$ & NS & 1.075 & 0.800 & 1.247 & 1.443 & - & - & NS & 1.429 & 1.222 \\
\hline
\end{tabular}

Table 4: Effect of organic manures and bio-inoculants on collar girth for seedlings of TS-462 and clonal plants of TV 26

\begin{tabular}{|c|c|c|c|c|c|c|c|c|c|c|}
\hline \multirow[b]{3}{*}{ Treatment } & \multicolumn{10}{|c|}{ Collar girth $(\mathrm{mm})$ per plant on DAS/ DAT } \\
\hline & \multicolumn{5}{|c|}{ TS-462 } & \multicolumn{5}{|c|}{$\begin{array}{r}\text { TV } 26 \\
\end{array}$} \\
\hline & 120 & 210 & 300 & 390 & 480 & 120 & 210 & 300 & 390 & 480 \\
\hline $\mathrm{T}_{1}(\mathrm{CONTROL})$ & $3.67^{b}$ & $9.05^{\mathrm{ab}}$ & $10.78^{c}$ & $12.50^{c}$ & 16.23 & $4.61^{\mathrm{a}}$ & $6.88^{b}$ & $9.33^{b}$ & $11.78^{b}$ & $11.51^{b}$ \\
\hline $\mathrm{T}_{2}$ Soil + FYM & $3.83^{\mathrm{b}}$ & $8.38 \mathrm{abc}$ & $12.04^{b c}$ & $15.70^{b}$ & 17.79 & $3.83^{b}$ & $7.22 \mathrm{ab}$ & $10.54^{b}$ & $13.87^{b}$ & $13.86^{\mathrm{ab}}$ \\
\hline $\mathrm{T}_{3}$ Soil + VC & $4.61^{\mathrm{a}}$ & $8.18^{\mathrm{bc}}$ & $12.33^{\mathrm{abc}}$ & $16.49 \mathrm{ab}$ & 18.47 & $3.67^{b}$ & $7.24^{\mathrm{ab}}$ & $9.63^{b}$ & $12.03^{b}$ & $13.33 \mathrm{ab}$ \\
\hline $\mathrm{T}_{4}$ Soil + BF & $3.98^{b}$ & $7.91^{\mathrm{c}}$ & $12.34^{\mathrm{abc}}$ & $16.77^{a b}$ & 16.75 & $3.97^{b}$ & $6.97^{a b}$ & $9.24^{\mathrm{b}}$ & $11.51^{b}$ & $12.55^{b}$ \\
\hline $\mathrm{T}_{6}$ Soil + VC+BF & $4.66 \mathrm{a}$ & $8.58^{a b c}$ & $13.84^{\mathrm{a}}$ & $19.10^{\text {a }}$ & 19.36 & $4.65^{\mathrm{a}}$ & $7.84^{\mathrm{a}}$ & $10.46^{\mathrm{b}}$ & $13.08^{b}$ & $13.86^{\mathrm{ab}}$ \\
\hline SEm $( \pm)$ & 0.189 & 0.294 & 0.515 & 0.906 & 0.979 & 0.189 & 0.288 & 0.411 & 0.755 & 1.277 \\
\hline CD at (0.05) & 0.561 & 0.874 & 1.532 & 2.691 & NS & 0.561 & 0.855 & 1.222 & 2.243 & 3.795 \\
\hline $\mathrm{CD}$ at $(0.01)$ & 0.768 & 1.198 & 2.098 & 3.688 & NS & 0.769 & 1.171 & 1.674 & 3.073 & 5.200 \\
\hline
\end{tabular}

at 3:1 and improved the overall nutrient status of the soil. Addition of $250 \mathrm{~g}$ of vermicompost to the soil and foliar application of vermiwash to the potted tea plants at fortnightly interval after centering showed significant increase in number of branches (Radhakrishnan and Mahendran 2010). The clone T-78 performed best in respect of branches per plant (7.33) as compared to other clones (Choubey et al. 2013). Better production of vegetative parts in the present investigation might be due to the presence of various biologically active metabolites such as plant growth regulators (Tomati and Galli 1995; El Harti et al. 2001) and humates (Atiyeh et al. 2002; Canellas et al. 2002; Forde and Lorenzo 2001).

It is clear from Table 4 that observations recorded on girth of plants at collar region in tea seedlings of stock TS-462 ranged from $3.67 \mathrm{~mm}$ to 19.36 $\mathrm{mm}$. Maximum girth of $4.79 \mathrm{~mm}$ was observed in $\mathrm{T}_{5}$ (Soil + FYM + biofertilizers) on 120 DAS followed by 4.66 in $\mathrm{T}_{6}$ (Soil $+\mathrm{VC}+$ biofertilizers) and minimum girth of $3.67 \mathrm{~mm}$ was observed in $\mathrm{T}_{1}$ (control). However, the girth of the seedlings under
$\mathrm{T}_{3}$ (4.61) and $\mathrm{T}_{6}$ (4.66) were at par with $\mathrm{T}_{5}$ (Soil + FYM + biofertilizers). On 210 DAS maximum plant girth of $9.31 \mathrm{~mm}$ was recorded in $\mathrm{T}_{5}$ (Soil + FYM + biofertilizer) and minimum $7.91 \mathrm{~mm}$ was observed in $\mathrm{T}_{4}$ (Soil + biofertilizers). On 300 and 390 DAS maximum plant girth of $13.84 \mathrm{~mm}$ and $19.10 \mathrm{~mm}$ respectively were recorded in treatment $\mathrm{T}_{6}$ (Soil + VC + biofertilizers) and minimum $10.78 \mathrm{~mm}$, $12.50 \mathrm{~mm}$ were observed in $\mathrm{T}_{1}$ (control). Finally, observation on 480 DAS showed non significant variation among various treatments. Perusual of data presented for clonal plants of TV 26, in Table 4.01.04 revealed that maximum girth at collar region on 120 DAT was $4.78 \mathrm{~mm}$ in $\mathrm{T}_{5}$ (Soil + FYM + biofertilizers), which was at par (4.65 $\mathrm{mm}$ and 4.61 $\mathrm{mm}$ ) with treatment $\mathrm{T}_{6}$ (Soil $+\mathrm{VC}+$ biofertilizers) and $\mathrm{T}_{1}$ (Control). A minimum girth of $3.67 \mathrm{~mm}$ was recorded on $120 \mathrm{DAT}$ in $\mathrm{T}_{3}$. On $210 \mathrm{DAT}$ maximum girth of $7.84 \mathrm{~mm}$ was recorded in treatment T6 (Soil $+\mathrm{VC}+$ biofertilizers) and minimum of $6.88 \mathrm{~mm}$ was observed in $\mathrm{T}_{1}$ (control). On subsequent observations on 300, 390 and 480 DAT maximum girth of 12.41 


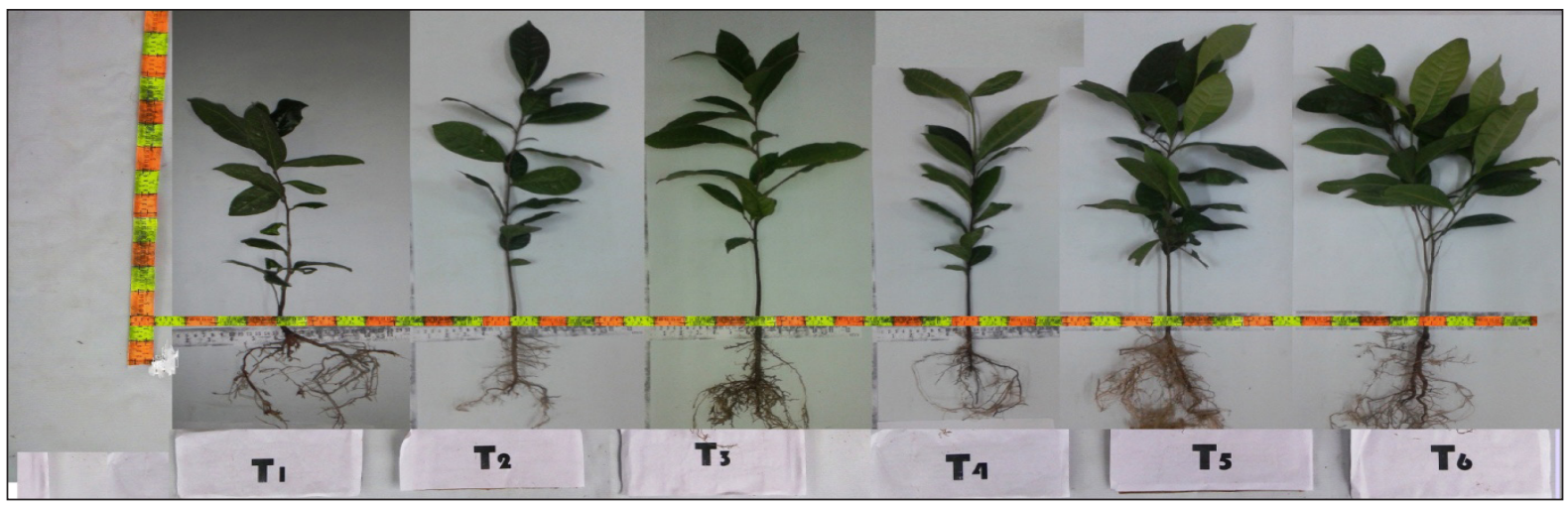

Performance of tea seed stock (TS-462) on 300 days after sowing

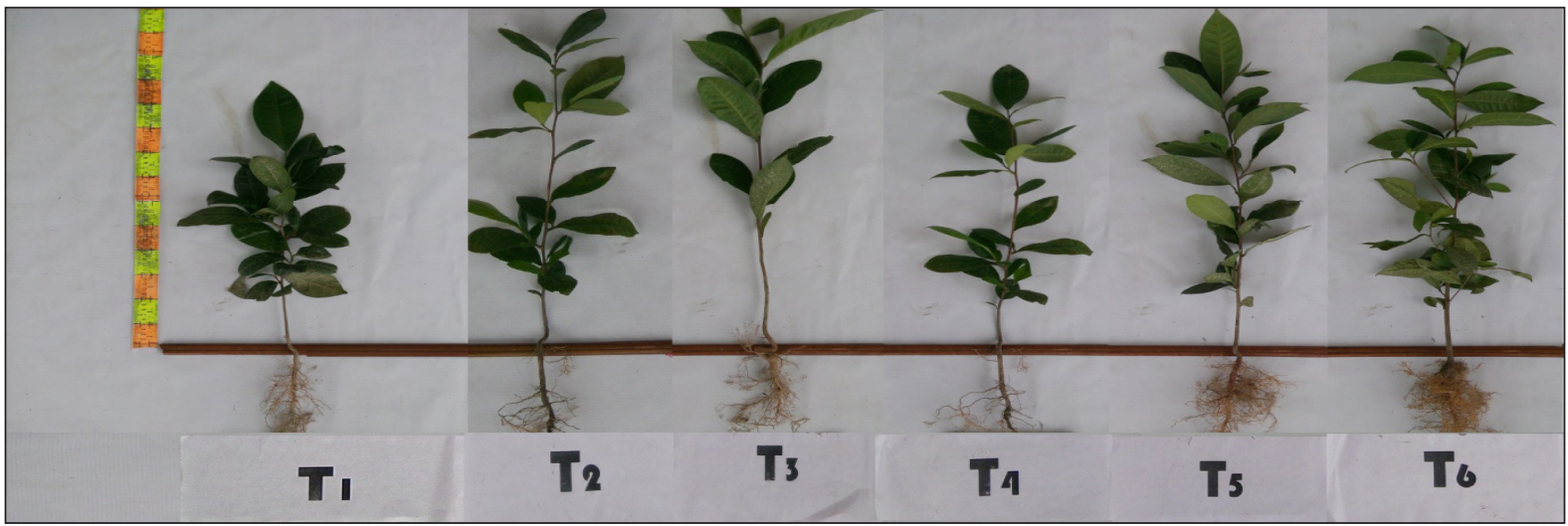

Performance of tea seed stock (TS-462) on 390 days after sowing

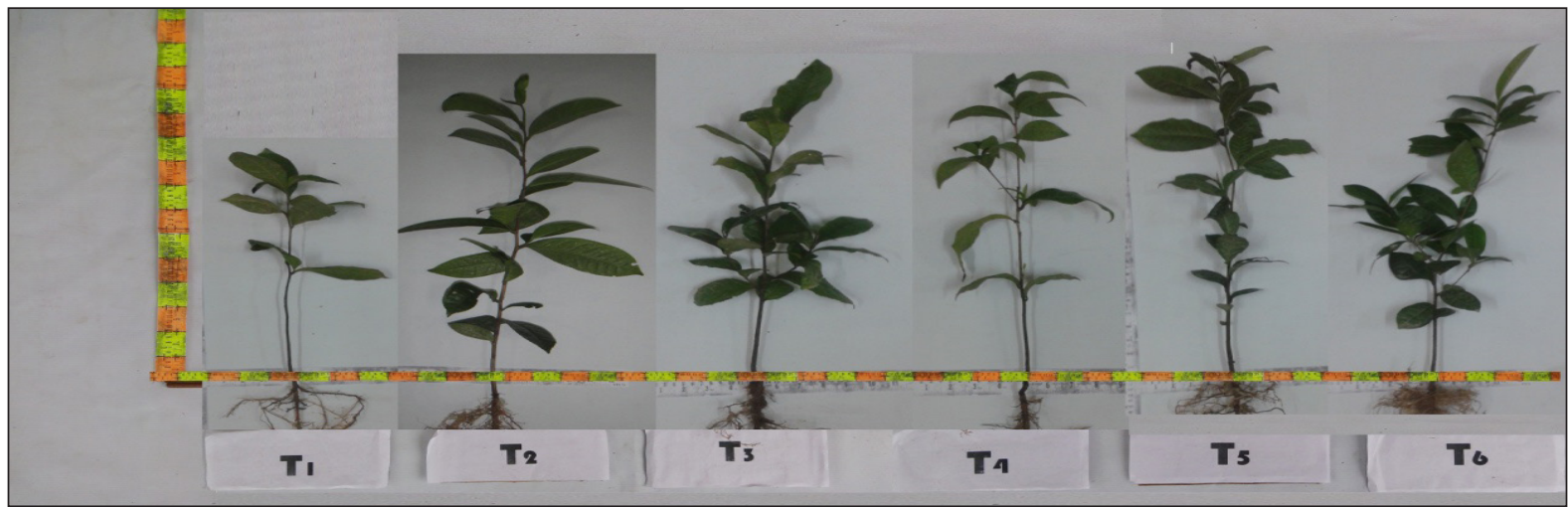

Performance of tea clone (TV 26) on 300 days after transplanting

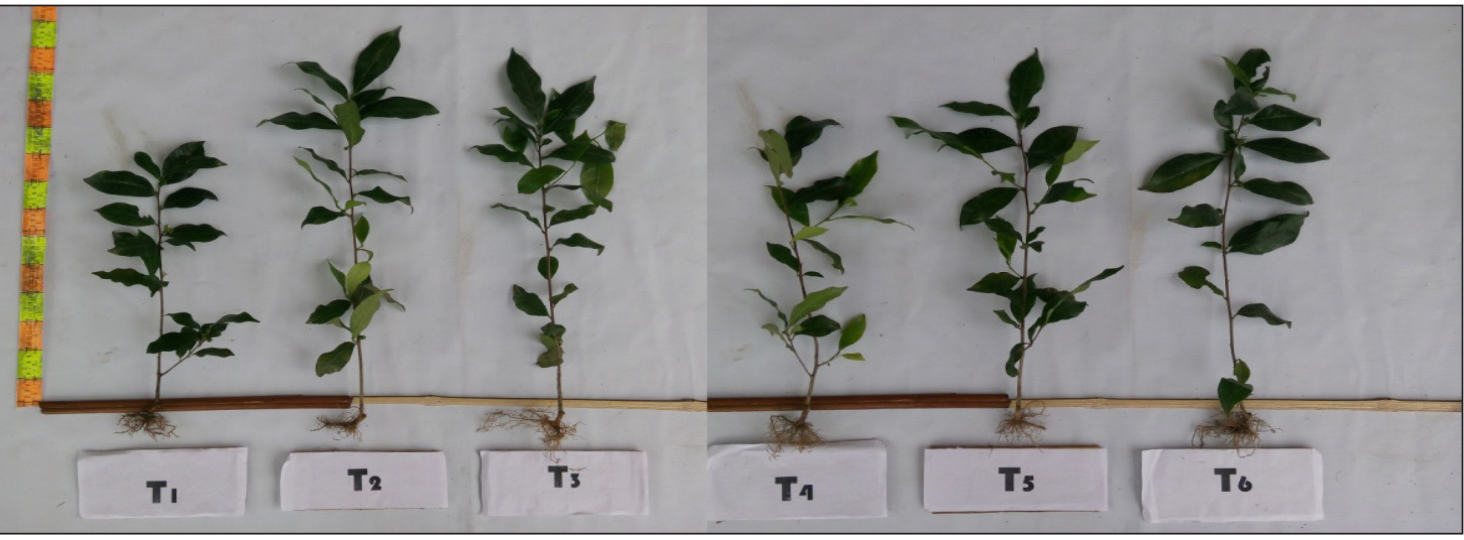

Performance of tea clone (TV 26) on 390 days after transplanting 
$\mathrm{mm}, 17.22 \mathrm{~mm}$ and $17.26 \mathrm{~mm}$ were recorded in $\mathrm{T}_{5}$ (Soil + FYM + biofertilizers) and minimum of 9.24

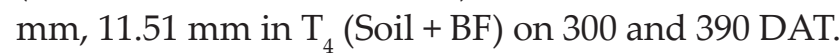
The data from Table 4.01.04 revealed that there were significant differences among all the treatment combinations and observations for girth of plant at collar region, in both the planting materials seed stock TS-462 and clone TV 26, except in tea seedlings of stock TS-462 on 480 DAS which was observed to be non-significant.

Maximum plant girth at collar of $13.84 \mathrm{~mm}$ and $19.10 \mathrm{~mm}$ on 300 and 390 DAS, respectively were recorded in treatment $\mathrm{T}_{6}($ Soil $+\mathrm{VC}+\mathrm{BF})$ and minimum of $10.78 \mathrm{~mm}$ and $12.50 \mathrm{~mm}$ were observed in $\mathrm{T}_{1}$ (control). Finally, observation on 480 DAS showed non significant variation among various treatments. While, for clonal plants of TV 26, maximum girth of $12.41 \mathrm{~mm}, 17.22 \mathrm{~mm}$ and $17.26 \mathrm{~mm}$ were recorded in $\mathrm{T}_{5}($ Soil $+\mathrm{FYM}+\mathrm{BF})$ and minimum of $9.24 \mathrm{~mm}, 11.51 \mathrm{~mm}$ in $\mathrm{T}_{4}$ (Soil + BF) on 300 and 390 DAT (Table 4.01.04). There were significant differences among all the treatments combinations and observations for girth of plant at collar in both the planting materials i.e.,seed stock (TS-462) and clone (TV 26), except in tea seedlings of TS-462 on 480 DAS. Osman, (2010) revealed that the combination of BF and NPK fertilizer treatments significantly increased number of shoots, number of leaves per shoot, shoot length, shoot diameter, leaf area, leaf fresh and dry weights, N, P and K contents in olive leaves.

In the nursery, clones of tea species exhibit variations due to their inherent qualities, besides nutritional and hormonal factors (George and Sherrington, 1984). Radhakirshnan and Mahendran (2010); Saikia et al. (2008); Saloi and Deka (1996); Phukan et al. (2002) and Navamaniraj (2008) also reported similar observations. All the morphological parameters observed in treatments with organic manures amended with bio inoculants showed better performance over other treatments. In biclonal seed stocks, bio inoculants alone recorded higher values of chlorophyll content followed by $100 \%$ IOF + BF and 100\% IOF alone during 12 months period of observation. The nitrogen fixers and phosphobacteria with phosphate mobilizer present might have helped in increasing various growth parameters by exerting synergistic effect with inorganic and biofertilizers (Balamurugan et al. 2013).

In case of TS-462, seedlings with better morphological traits were obtained when soil was added with bio-fertilizers in combination with vermicompost. While, in clones, biofertilizers along with farm yard manure as potting mixture showed better results. The growth performance of plant height, biofertilizers with vermicompost treated seedlings of TS-462 exhibited a growth rate of $1.40 \mathrm{~mm} /$ day as compared to about $0.70 \mathrm{~mm}$ per day only in controlled plants $\left(\mathrm{T}_{1}\right)$. In case of clone (TV 26), growth rate of $1.00 \mathrm{~mm}$ per day against $0.60 \mathrm{~mm}$ in control. Interpretation of treatment efficiency showed that the treatment $\left(\mathrm{T}_{6}\right)$ i.e., combination of biofertilizers with vermicompost resulted in $46.7 \%$ more efficiency than controlled $\left(\mathrm{T}_{1}\right)$ on final observation i.e., 480 DAS in seedling of TS-462. However, in clones treatment efficiency was less as compared to seedlings with inoculation efficiency of $28.7 \%$. The days required to reach standard height of transplantable planting material was calculated with the help of the linear equation for height against days after sowing. Upon calculation it was found that the standard plant height for ideal planting material of tea $(40$ to $45 \mathrm{~cm}$ ) could be achieved within 348 days in treated plants against 600 days for controlled $\left(\mathrm{T}_{1}\right)$ seedlings. In case of clone, the growth rate was comparably slower, recommended standard was reached in treatment $\left(\mathrm{T}_{6}\right)$ i.e., biofertilizers with vermicompost combination on 470 DAT in comparison to control which took 693 days (Saikia et al. 2008; He et al. 1994). So, an advantage of treatment of addition of $\mathrm{VC}$ and BF with respect to plant height in comparison to control was recorded as 250 days earlier in seedlings and 224 days in clonal cuttings. The survival rates of Chin-shin Oolong tea cuttings were higher in beds in which $3.5 \mathrm{~kg}$ FYM + soil was incorporated as compared to control beds. Seedlings of TS-462 exhibited a growth rate of 0.09 leaves per day, when biofertilizers were added with vermicompost $\left(\mathrm{T}_{6}\right)$ as compared to 0.03 leaves per day in case of controlled plants. Whereas, in case of clonal plantlets 0.06 leave per day was observed over the untreated controlled plantlets with 0.03 leaves per day only. Interpretation of treatment efficiency in case of seedlings of TS-462 showed that, treatment $\mathrm{T}_{6}(\mathrm{VC}+\mathrm{BF})$ was 59.02 percent more efficient than 
control on 480 DAS. In clone, treatment efficiency was less as compared to seedlings with $33.50 \%$ over control. It was observed that optimum number of leaves for ideal planting material of tea is, in our findings the standard number of 16 healthy leaves was reached on 204 DAS for seedlings of TS-462 in biofertilizers with vermicompost treated plants where as in control plants it took 480 DAS. In case of clone, the growth rate was comparatively slower, where, the plantable plants with optimum number of leaves could be achieved in treatment $\mathrm{T}_{6}(\mathrm{VC}+$ $\mathrm{BF})$ on 346 DAT in comparison to control, which took more than 480 days. Wachira and Kamunya, (2004) reported that black artificial shading materials with $40-90 \%$ shading capacity are suitable for use in tea nurseries.

Number of branches and girth of the plant at collar with the treated plants showed a treatment efficiency of $87.6 \%$ and $14.6 \%$ respectively for seed stock. Clone also behaved accordingly with efficiency of $51.6 \%$ and $25.01 \%$ for number of branches and girth of the plant respectively, which might be due to vermicompost combined with $\mathrm{BF}$ enhanced mobilization and uptake of nutrients for production of elite seedlings in the nursery (Navamaniraj et al. 2008). Vermicompost contains $\mathrm{N}, \mathrm{P}, \mathrm{K}, \mathrm{Mg}, \mathrm{Ca}$ and vitamins that regulated the plant growth (Sreekrishnabhat 1999). Vermicompost enhanced the macro and micronutrient uptake by the plants which might have enhanced the biological activities in the rhizosphere (Sivasubramanian 1999). Mixing of vermicompost with the growing medium improved the overall nutrient status of soil and reduced the growth duration of plants (Radhakirshnan and Mahendran 2007). In all the treatments the seedlings responded better than the clonal plantlets (Kamau 2008). Bigger plants with bigger root system suffered less casualties in the field during vagaries of weather (Scarborough and Kayange 1974). Concentrated organic manures resulted in significantly higher growth of the plants (Phukan et al. 2002).

\section{CONCLUSION}

As our country giving emphasis on organic cultivation and moving towards a sustainable agriculture for bright future, fulfilling the gaps such as organic planting material production in concern to commercial crops like tea is necessary. So considering the importance of organic farming and requirement of organic planting materials for tea, potting mixture containing soil with vermicompost @ 50 g or FYM @ 100 g and Bio-inoculants viz., Azotobacter, Azospirillium, PSB, Trichoderma and VAM @ 2 g each per sleeve produced plantable plants from the seedlings of TS-462 and cuttings of TV 26 with best morphological characters within 300-390 days after sowing or days after transplanting respectively.

\section{REFERENCES}

Aggani, S.L. 2013. Development of Bio-Fertilizers and its Future Perspective. Scholars Academic Journal of Pharmacy, 2(4): 327-332.

Atiyeh, R.M., Lee, S., Edwards, C.A., Arancon, N.Q. and Metzger, J.D. 2002. The influence of humic acids derived from earthworm-processed organic wastes on plant growth. Bioresource Technology. 84: 7-14.

Balamurugan, A., Jayanthi, R., Muthukannan, P., Sanmugapriyan, R., Kuberan, T. and Premkumar, R. 2013. Integrated nutrient management by using bioinoculants in seedlings of tea (Camellia sinensis) under nursery. International Journal of Advancements in Research $\mathcal{E}$ Technology, 2(12): 245-256.

Cacciari, D.L. and Pietrosanti, T. 1989. Phytohormones like substances produced by single and mixed diazotrophic cultures of Azospirillum and Arthrobacter, Plant and Soil, 115: $152-159$.

Canellas, L.P., Olivares, F.L., Okorokovafacanha, A.L. and Facanha, A.R. 2002. Humic acids isolated from earthworm compost enhance root elongation, lateral root emergence, and plasma membrane $\mathrm{H}+$-ATPase activity in maize roots. Plant Physiology, 130: 1951-1957.

Choubey, M., Kumar, R., Chakraborty, A., Bisen, J.S., Singh, A.K. and Singh, M. 2013. Performance of tea clones in the nursery through vegetative propagation in Darjeeling. Int. J. Sci., 3(11): 1-4.

El Harti A., Saghi M., Molina J.A.E. and Teller G. 2001. Production des composés indoliques rhizogénes par le ver de terre Lumbricus terrestris. Can J Zool-Rev Can. Zool., 79: 1921-1932.

FAO, 2014. Working group on organic Tea. Intersessional meeting of the intergovernmental group on tea, Rome: May, 5-6.

Fisher, S.R.A. and Yates, F. 1963. Statistical Tables for Biology, Agricultural and Medical Research. Oliver and Boyd. Edinburgh Tweedale Court, London (6 $6^{\text {th }}$ Edn.).

Forde, B. and Lorenzo, H. 2001. The nutritional control of Root development. Plant Soil, 232: 51-68.

George, E.F. and Sherrington, P.O. 1984. Plant propagation by tissue culture. Hand book and directory of commercial laboratories. Exegetic Limited, London. 
Goswami, R. 2015. Big push for organic tea in India The Telegraph Calcutta times news paper $4^{\text {th }}$ June; Report of the working group on organic tea, $2^{\text {nd }}$ intersessional meeting on $6^{\text {th }}$ May, 2014.

He, S.L., Liu, B.Y., Fang, D.H., Wang, S.S., Lei, Z.Z. and Wang, D.J. 1994. Effects of VA mycorrhiza (Glomus epigaeum) on the mineral nutrition for Camellia sinensis and their mechanisms. Journal of Southwest Agricultural University, 16(5): 492-496.

IBEF, 2016. India Brand Equity Foundation. www. teacoffeespiceofindia.com.

Islam, S., Qamar-uz-Zaman., Hamid, F.S., Ahmad, F., Waheed, A., Shah, B.H., Sohail Aslam, S. and Hussain, S. 2015. Impact of different fertilizer mixtures on growth performance of tea cuttings. Journal of Agricultural Research (Lahore). 53(2): 203-208.

Kamau, D.M. 2008. Productivity and resource use in ageing tea plantations. Wageningen University, Wageningen, Netherlands. (Book) Productivity and resource use in ageing tea plantations, pp. 140.

Kushwaha, D.S. 2011. Comparison of effect of biofertilizers on seedling growth and available nutrients in soil of sesame (Sesamum indicum) varieties. Journal of Environmental Research and Development, 5(3): 631-637.

Laila, F. Haggag, Shahin, M.F.M., Mahdy H.A., Amira K.G., Atteya and Hassan H.S.A. 2015. Beneficial effect of NPK, pigeon manure tea and microbial fertilizers as soil application on growth of "Toffahi" and "Picual" olive seedlings. Journal of Agricultural Technology, 11(7): 1565-1582.

Majumder, A.B., Bera B. and Rajan, A. 2012. Tea Statistics: Global Scenario. Inc. J. Tea Sci., 8(1): 121-124.

Mamaril, C.P., Rosales, R.T. and Cabrora, M.S. 1986. Inorganic nitrogen fertilizer and green manure in lowland rice. Paper presented at the INSFFER Planning Meeting Workshop in Hangzhon, China, Sept., 22-24.

Marschner, P. 2012. Marschner's Mineral Nutrition of Higher Plants. $3^{\text {rd }}$ ed. Academic Press, London, UK: 178-189.

Navamaniraj, K.N., Srimathi, P. and Ponnuswamy, A.S. 2008. Influence of potting mixture on elite seedling production in Bixa orellana. Madras Agric. J., 95(7-12): 496-498.

Osman, S.M., 2010. Effect of mineral, Bio-NPK soil application of young olive trees and foliar fertilization on leaf and shoot chemical composition. Res. J Agric. and Bio. Sci., 6: 311-318.

Pandya, U. and Saraf, M. 2010. Application of fungi as a biocontrol agent and their biofertilizer potential in agriculture. J. Advan. Develop. and Res., 1: 90-99.
Phukan, I., Barooah, A.K., Singh Y., Gohain, K.K., Dutta, A.K. and Kotoky, A. 2002. Effect of a few organic manures on growth of tea, soil properties and bioavailability of their heavy metal contents. Two and a Bud., 49: 38-45.

Prayukth, K.V. 2005. Coomunications Coordinator at the Indo Norwegian Environment Program in Bangalore.

Priya, S. and Elakkiya, R. 2012. Effect of organic and biofertilizers on growth and Yield of Eclipta alba(l.). International Journal of Pharmtech Research, 4(4): 1703-1705.

Radhakrishnan, B. and Mahendran, P. 2007. Effect of vermicompost on growth and development of nursery plants. Newsletter- UPASI Tea Research Foundation, 17(1): 5-6.

Radhakrishnan, B. and Mahendran, P. 2010. Studies on the effect of vermicompost and vermiwash on growth and development of tea (Camellia sinensis). Journal of Plantation Crops, 38(1): 27-31.

Rajendran, K. and Jayasree, R. 2007. Effect of Biofertilizers on quality seedling production of Acacia nilotica. Journal of Non-timber Products, 14: 5-11.

Ramakrishnan, K. and Selvakumar, G. 2012. Effect of biofertilizers on enhancement of growth and yield on Tomato (Lycopersicum esculentum Mill.). International Journal of Research in Botany, 2(4): 20-23.

Saikia, G.K., Deka, A., Barbora, A.C. and Bhuyan R.P. 2008. Growth, development and yield of tea (camellia sinensis L. O. Kuntze) Plants as affected by organic cultivation. Journal of Plantation Crops, 36(2): 103-107.

Saloi, B.K. and Deka, M. 1996. Growth of young clonal tea as influenced by supplementation of organic manure. Journal of the Agricultural Science Society of North East India, 9(1): 79-81.

Scarborough, T.P. and Kayange, C.W. 1974. Annual report of Tea Research Foundation of Central Africa 1973. Mulanji, Malawi. 112.

Sivasubramanian, K. 1999. Effect of earthworms and their metabolites on biological productivity. M.Sc. (Ag.) Thesis, Tamil Nadu Agricultural University, Coimbatore.

Sreekrishnabhat, S. 1999. Organic farming-An ecofriendly agriculture for spices growing. Spice India, 12(3): 7-10.

Timsina, J. and Connor, D.J. 2001. Productivity and management of rice-wheat systems: Issues and challenges. Field Crops Research, 69: 93-132.

Tomati, U. and Galli, E. 1995. Earthworms, soil fertility and plant productivity. Acta Zoologica Fennica, 196: 11-14.

Wachira, F.N. and Kamunya, S.M. 2004. Performance of single leaf cuttings of tea grown under artificial shading materials of different shade intensities. Tea, 25(1). 
